\title{
The Chediak-Higashi Protein Interacts with SNARE Complex and Signal Transduction Proteins
}

\author{
Velizar T. Tchernev, ${ }^{1,2}$ Traci A. Mansfield, ${ }^{1}$ Loic Giot, $^{1}$ A. Madan Kumar, ${ }^{1}$ Krishnan Nandabalan, $^{1}$ \\ Ying Li, ${ }^{1}$ Vishnu S. Mishra, ${ }^{1,2}$ John C. Detter, ${ }^{2}$ Jonathan M. Rothberg, ${ }^{1}$ Margaret R. Wallace, ${ }^{2}$ \\ Frederick S. Southwick, ${ }^{2}$ and Stephen F. Kingsmore ${ }^{1,2}$ \\ ${ }^{1}$ CuraGen Corporation, New Haven, CT, USA \\ ${ }^{2}$ Departments of Medicine, Pathology and Laboratory Medicine, Pediatrics, and Center for Mammalian \\ Genetics, University of Florida, Gainesville, FL, USA
}

Accepted December 21, 2001

\begin{abstract}
Background: Chediak-Higashi syndrome (CHS) is an inherited immunodeficiency disease characterized by giant lysosomes and impaired leukocyte degranulation. CHS results from mutations in the lysosomal trafficking regulator (LYST) gene, which encodes a $425-\mathrm{kD}$ cytoplasmic protein of unknown function. The goal of this study was to identify proteins that interact with LYST as a first step in understanding how LYST modulates lysosomal exocytosis. Materials and Methods: Fourteen cDNA fragments, covering the entire coding domain of LYST, were used as baits to screen five human cDNA libraries by a yeast twohybrid method, modified to allow screening in the activation and the binding domain, three selectable markers, and more stringent confirmation procedures. Five of the interactions were confirmed by an in vitro binding assay.
\end{abstract}

Results: Twenty-one proteins that interact with LYST were identified in yeast two-hybrid screens. Four interactions, confirmed directly, were with proteins important in vesicular transport and signal transduction (the SNAREcomplex protein HRS, 14-3-3, and casein kinase II).

Conclusions: On the basis of protein interactions, LYST appears to function as an adapter protein that may juxtapose proteins that mediate intracellular membrane fusion reactions. The pathologic manifestations observed in CHS patients and in mice with the homologous mutation beige suggest that understanding the role of LYST may be relevant to the treatment of not only CHS but also of diseases such as asthma, urticaria, and lupus, as well as to the molecular dissection of the CHS-associated cancer predisposition.

\section{Introduction}

Lysosomes have unique and fascinating abnormalities in Chediak-Higashi syndrome (CHS), a primary immunodeficiency disease. They are greatly enlarged, limited to the perinuclear region, lack critical cargo proteins, and are dilatory in heterotypic membrane fusion (1-3). The clinical features of CHS of recurrent infections, albinism, and bleeding diathesis reflect these defects. Recurrent infections, for example, result from secretory granule protein missorting and impaired leukocyte exocytosis (4-6). Albinism occurs as a result of tyrosinase deficiency in CHS melanocytes due to exocytosis instead of delivery to the melanosome (7). Absence of dense granules in CHS platelets leads to a bleeding tendency (8).

Identification of the causal gene (LYST) failed to explain the lysosomal abnormalities of CHS; LYST encodes a $425-\mathrm{kD}$ cytosolic protein that is ubiquitously expressed but of unknown function (9-12). Structurally, LYST is novel and unlike other proteins implicated in vesicular transport. Although LYST

Correspondence and reprint requests should be addressed to: V.T. Tchernev, Molecular Staging, 300 George Street, 7th Floor, New Haven, CT 06511. Phone: (203) 772-5097;

fax: (203) 776-5276; e-mail: velizart@molecularstaging.com contains C-terminal WD40 repeats, HEAT/ARM domains, a region with weak similarity to stathmin, and multiple potential sites of phosphorylation by casein kinase II (CK2) and protein kinase C (PKC), the significance of these features is unknown.

Understanding the mechanism whereby LYST defects cause CHS is important for treatment both of CHS and diseases associated with inappropriate exocytosis, such as asthma and urticaria. Using a recently described, modified yeast two-hybrid ( $\mathrm{Y} 2 \mathrm{H})$ method (13), proteins that interact with LYST were identified. These interactions suggest LYST to act as a scaffold for SNARE complex proteins.

\section{Materials and Methods Cloning of LYST cDNA Fragments in $Y 2 H$ Vectors}

Fourteen overlapping LYST cDNA fragments covering the coding domain were PCR amplified and cloned in the yeast Gal4 activation domain (AD) cloning vector, pAD-GAL4 (modified pGAD-GH, Clontech, Palo Alto, CA, USA), and the Gal4 DNAbinding domain (BD) vector, pGB-GAL4 (modified pGBT9, Clontech). Primers generated in-frame cDNA fragments that preserved LYST protein domains (Table 1). Clones were sequenced to ensure fidelity. 
Table 1. Primers used to amplify LYST cDNA fragments

\begin{tabular}{|c|c|c|c|}
\hline $\begin{array}{l}\text { LYST Bait, } \\
\left(\text { (bp*) }^{*}\right.\end{array}$ & $\begin{array}{c}\text { Primer Sequence, } 5^{\prime} \rightarrow 3^{\prime} \\
\text { (forward, upper sequence; reverse, lower sequence) }\end{array}$ & $\begin{array}{l}\text { Restriction } \\
\text { Enzyme }\end{array}$ & $\begin{array}{l}\text { Bait Size } \\
\quad(\text { bp) }\end{array}$ \\
\hline $190-1056$ & $\begin{array}{l}\text { GCGGTGGATCCCATGAGCACCGACAGTAACTCAC } \\
\text { GCGGAATTCTCATAGTGTGGGCACTACACTGG }\end{array}$ & $\begin{array}{l}\text { BamHI } \\
\text { EcoRI }\end{array}$ & 866 \\
\hline $\begin{array}{l}1051-1950 \\
\text { stathmin-like }\end{array}$ & $\begin{array}{l}\text { GCGGTGGATCCCACACTAACTGAGTTCCTAGCAGGCTTTGGGGACTGC } \\
\left(\text { GAGAGA) }{ }_{3} \text { CTCGAGTCAATCCATACAACAGCATATTCCAATG }\right.\end{array}$ & $\begin{array}{l}\text { BamHI } \\
\text { Xhol }\end{array}$ & 899 \\
\hline $1948-2370$ & $\begin{array}{l}\text { GCGGAACTAGTGGATCCCAAATCTGTAATCATTCC } \\
\text { GGAATTCTCACTGAACAАCTATATTGCСTTTCTG }\end{array}$ & $\begin{array}{l}\text { SpeI } \\
\text { EcoRI }\end{array}$ & 422 \\
\hline $2347-3213$ & $\begin{array}{l}\text { GCGAGTGTGGATCCCCAGAAAGGCAATATAGTTGTTCAG } \\
\text { GCGGAATTCTCACTCСТCTTTGTGACTTCTGAAC }\end{array}$ & $\begin{array}{l}\text { BamHI } \\
\text { EcoRI }\end{array}$ & 866 \\
\hline $3190-4032$ & $\begin{array}{l}\text { GCGGTGGATCCCCTGTTCAGAAGTCACAAAGAGG } \\
\text { GGAATTCTCAAGCAGAAAGCAAATTTAATTCCAG }\end{array}$ & $\begin{array}{l}\text { BamHI } \\
\text { EcoRI }\end{array}$ & 842 \\
\hline $4009-4821$ & $\begin{array}{l}\text { GCGGTGGATCCCCTGGAATTAAATTTGCTTTCTGC } \\
\text { GCGGAATTCTCAGGAGCCCAGTGAAATTATATG }\end{array}$ & $\begin{array}{l}\text { BamHI } \\
\text { EcoRI }\end{array}$ & 812 \\
\hline $4819-5700$ & $\begin{array}{l}\text { GCGGTGGATCCСTCCAAAGCGTTGATGATCCAAG } \\
\text { GCGGAATTCTCAAACTCGCAGTGCTAATGCTTG }\end{array}$ & $\begin{array}{l}\text { BamHI } \\
\text { EcoRI }\end{array}$ & 881 \\
\hline $5677-6612$ & $\begin{array}{l}\text { GCGGTGGATCCCACTCAAGCATTAGCACTGCGAG } \\
\left(\text { GAGAGA) }{ }_{3} \text { CTCGAGTCAGGCAACATAAGTATCTGCAATATTTTG }\right.\end{array}$ & $\begin{array}{l}\text { BamHI } \\
\text { Xhol }\end{array}$ & 935 \\
\hline $6586-7449$ & $\begin{array}{l}\text { GCGGTGGATCCCCAAAATATTGCAGATACTTATGTTGCC } \\
\text { GCGGAATTCTCATCCCATGTTTCTCACATCTTCCAG }\end{array}$ & $\begin{array}{l}\text { BamHI } \\
\text { EcoRI }\end{array}$ & 863 \\
\hline $7426-8238$ & $\begin{array}{l}\text { GCGGTGGATCCCCTGGAAGATGTGAGAAACATGGG } \\
\text { GCGGAATTCTCAGGTCTGGAAAACTGAGGTCTTG }\end{array}$ & $\begin{array}{l}\text { BamHI } \\
\text { EcoRI }\end{array}$ & 812 \\
\hline $8218-9039$ & $\begin{array}{l}\text { GCGGTGGATCCCAAGACCTCAGTTTTCCAGACCG } \\
\text { GCGGAATTCTCAATCCAACTGCCATGAGGTTGG }\end{array}$ & $\begin{array}{l}\text { Bam HI } \\
\text { EcoRI }\end{array}$ & 821 \\
\hline 9037-9585 & $\begin{array}{l}\text { GCGGTGGATCCCGATCCAACAGAAGGGCCAAATC } \\
\text { GCGGAATTCTCATGTCAGAGCGGTGATGTTACC }\end{array}$ & $\begin{array}{l}\text { Bam HI } \\
\text { EcoRI }\end{array}$ & 548 \\
\hline $\begin{array}{l}9502-10590 \\
\text { BEACH dom. }\end{array}$ & $\begin{array}{l}\text { GCGGTGGATCCCAAGGTTCGTGATGATGTATACCAC } \\
\text { GCGGAATTCTCACAAGCCTTTTATCCATGACAAAGG }\end{array}$ & $\begin{array}{l}\text { Bam HI } \\
\text { EcoRI }\end{array}$ & 1088 \\
\hline $\begin{array}{l}10576-11611 \\
\text { WD-40 dom. }\end{array}$ & $\begin{array}{l}\text { GCGGTGGATCCСTGGATAAAAGGCTTGAAATGGGG } \\
\text { GCGGAATTCTCATGAAGTTCATTCGCATTCACCC }\end{array}$ & $\begin{array}{l}\text { BamHI } \\
\text { EcoRI }\end{array}$ & 1035 \\
\hline
\end{tabular}

*From GenBank \# U67615.

Human cDNA Libraries Used in Y2H Screens

cDNA from human fetal brain mRNA (Clontech) was cloned into Gal4 AD of HybriZap 2.1 (Stratagene, La Jolla, CA, USA) to generate a phage cDNA library with $6 \times 10^{6} \mathrm{pfu}$ and $>90 \%$ recombinant clones. Following in vivo excision, $300 \mu \mathrm{g}$ of recombinant plasmid was transformed into yeast strain N106r (MAT $\alpha$, ura3, his3, leu2, gal4, gal80, ade2,

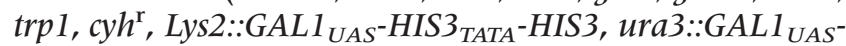
$G A L_{T A T A}$-lacZ, ), with selection on synthetic complete medium lacking leucine (SC-Leu). Transformants $\left(7 \times 10^{7}\right)$ were used for forward screens.

A human fetal brain cDNA library $\left(1.5 \times 10^{7}\right.$ pfu, $>90 \%$ recombinant clones) was constructed in HybriZap modified to contain GAL4 BD. Four hundred micrograms of plasmid was transformed into yeast strain YULH (MAT a, ura3, his3, lys2, Ade2, trp1, leu2, gal4, gal80, GAL1-URA3, GAL1-lacZ) and selected on SC-Trp medium, and $1.5 \times 10^{8}$ transformants were used in reverse screens.
Human adult heart, adult keratinocyte, fetal liver, and fetal kidney cDNA libraries in the Gal4 AD vector pACT2 (HL4042AH, HL4030AH, HL4029AH and HL4008AB; Clontech) were amplified and plasmids purified. N106r yeast cells were transformed with $200 \mu \mathrm{g}$ of plasmid DNA and $10^{7}$ yeast transformants were used in screens.

\section{Forward and Reverse Y2H Screens}

In "forward" screens, strain YULH was transformed with LYST baits inserted in the Gal4 BD plasmid, and strain N106r was transformed with the prey cDNA library in the Gal4 AD vector (13). In "reverse" screens, LYST baits in the Gal4 AD plasmid were transformed in N106r, and the prey library fused to the Gal4 BD was transformed in YULH.

LYST bait DNA-binding domain clones were prescreened for intrinsic transcriptional activity. YULH yeast cells were transformed with pBD-GAL4 bait constructs, grown on SC-Trp medium (selection 
of $\mathrm{pBD}$ ), and then on SC-Ura medium overnight at $30^{\circ} \mathrm{C}$. Resultant colonies represented self-activating baits and were excluded. Promiscuous LYST baits were also excluded by prescreening against 50,000 prey library clones. Only baits that interacted with fewer than five proteins were used.

Screens entailed mating haploid strains: Following growth to late log phase on selective media, strains YULH and N106r were diluted in YPAD, applied to nitrocellulose membranes, and incubated at $30^{\circ} \mathrm{C}$ for $8 \mathrm{hr}$. Products were plated on SC Selective (SCS) medium (SC-Ade-Lys [selection of diploids], -Leu-Trp [selection of pAD and pBD], and -Ura-His [selection of reporter gene-activating protein interactions]). Colonies growing on SCS were replicated on Whatman No. 1 filters and assayed for $\beta$ galactosidase activity.

Confirmation of the Specificity of Protein Interactions by $\mathrm{Y} 2 \mathrm{H}$

Interacting proteins were tested for self-activation: YULH yeast cells were transformed with plasmids encoding $\mathrm{BD}$ fusion proteins of LYST-interacting proteins, grown at $30^{\circ} \mathrm{C}$ on SC-Trp medium (selection for BD plasmid) and then overnight on SC-Ura medium. Cells that did not grow lacked self-activating false-positives clones. Interactant self-activation was also tested using YULH and N106r yeast, transformed with LYST-interacting BD or AD fusion protein preys, respectively. These were grown on SC-Trp or SC-Leu media, and a filter-lift $\beta$-galactosidase assay was performed. Colonies that did not turn blue contained non-self-activating prey.

The specificity and reproducibility of interactions was evaluated in a matrix-mating test. BD fusions with baits (forward screen) or prey (reverse screen) were retransformed in YULH yeast, and AD fusions of baits (reverse screen) or prey (forward screen) were retransformed in N106r yeast and grown in YPAD medium at $30^{\circ} \mathrm{C}$. A matrix mating test was performed by spreading bait-containing haploid yeast over the surface of individual YPAD plates, followed by superimposing prey-containing haploids in a $12 \times 8$ matrix, and incubating the plates overnight at $30^{\circ} \mathrm{C}$. Each plate contained positive (known protein interaction pairs) and negative controls. Resulting diploid colonies were replicaplated both on SCS plates (to select for AD and BD plasmids, diploids, and protein interactions) and SC-Leu-Trp plates (that were used for a filter-lift $\beta$ galactosidase assay). Baits and prey from $\mathrm{LacZ}^{+}$ diploids growing on SCS were sequenced.

Expression and Affinity Purification of LYST-Interacting Proteins

LYST-interacting proteins (LIPs) were expressed as His-tag-T7 fusions by ligating PCR fragments of the corresponding genes in frame into PET-28a vector (Novagen, Madison, WI, USA). These constructs were transformed into Escherichia coli strain BL21DE3 (Novagen) and induced with isopropyl-b-D- thiogalactoside (IPTG). Cell pellets from $400 \mathrm{~mL}$ cultures were suspended in denaturing lysis buffer (20 mM Tris-HCl, pH 8.0, $500 \mathrm{mM} \mathrm{NaCl}, 5 \mathrm{mM}$ imidazole and $8 \mathrm{M}$ urea), sonicated on ice, and centrifuged. Supernatants were applied to Nickel-NTA columns (Novagen) pre-equilibrated with lysis buffer and washed with 10 volumes of wash buffer (20 mM Tris- $\mathrm{HCl}, \mathrm{pH} 8.0,500 \mathrm{mM} \mathrm{NaCl}, 50 \mathrm{mM}$ imidazole and $8 \mathrm{M}$ urea). Successive washes were performed with wash buffers containing urea concentrations of $4 \mathrm{M}, 2 \mathrm{M}, 1 \mathrm{M}, 0.5 \mathrm{M}, 0.2 \mathrm{M}, 0.1 \mathrm{M}$, $10 \mathrm{mM}$, and, finally, no urea. Bound protein was eluted with $20 \mathrm{mM}$ Tris- $\mathrm{HCl}, \mathrm{pH} 8.0,500 \mathrm{mM} \mathrm{NaCl}$, $500 \mathrm{mM}$ imidazole and eluted proteins were desalted by diafiltration (Amicon, Beverly, MA, USA).

Expression and Preparation of LYST Peptide-Solid Support

For expression as glutathione S-transferase (GST) fusions, LYST fragments were cloned in-frame in pGEX-5a (Amersham Pharmacia Biotech, Piscataway, NJ, USA) and transformed into E. coli strain BL2 1 (Amersham Pharmacia Biotech). GST fusion proteins were separated from cellular proteins by glutatione-sepharose column chromatography (Amersham Pharmacia Biotech): Cell pellets from IPTGinduced cultures were suspended in PBS containing $58 \mathrm{mM} \mathrm{Na} \mathrm{HPO}_{4}, 17 \mathrm{mM} \mathrm{NaH} \mathrm{PO}_{4}, 137 \mathrm{mM} \mathrm{NaCl}$ (pH 7.5), and protease inhibitors (Roche Molecular Biochemicals, Indianapolis, IN, USA). Suspensions were sonicated on ice, centrifuged to remove debris, and supernatants applied to glutathione-sepharose columns. Unbound proteins were removed with washes. Sepharose bound GST-fusion proteins were used in in vitro binding assays.

In Vitro Binding Assay

GST-LYST fragment fusion proteins bound to sepharose $(200 \mu \mathrm{L})$ were mixed with $200 \mu \mathrm{L}$ of purified, desalted LIP, or control protein, in PBS containing $1 \%$ Triton $\mathrm{X}-100$ and incubated at $24^{\circ} \mathrm{C}$ with rocking for $1 \mathrm{hr}$. Samples were centrifuged at 13,000 rpm for 1 min, supernatants discarded, and sepharose pellets were washed four times. Bound protein was then eluted with $300 \mu \mathrm{L}$ of $10-\mathrm{mM}$ reduced glutathione in $50 \mathrm{mM}$ of Tris- $\mathrm{HCl}(\mathrm{pH} \mathrm{8.0)}$. Eluted proteins were resolved on $8 \%$ SDS-PAGE and transferred to nitrocellulose. Membranes were probed with His-tag or T7-tag antibodies (Novagen), or with specific CK2, 14-3-3, or Hrs antisera, and detected with alkaline-phosphatase conjugated anti-mouse secondary antibodies.

\section{Results}

Yeast Two-Hybrid Screening

To screen a $425-\mathrm{kD}$ protein effectively, a recently described $\mathrm{Y} 2 \mathrm{H}$ modification (13) was used that includes screening in the activation or binding domain, three selectable markers, and stringent confirmation procedures. Cloning into the activation domain enables screening of self-activating baits. The 
use of three reporter genes ( $\beta$-galactosidase, and uracil and histidine auxotrophy) reduces false positives. The modified method also includes quality controls for bait self-activation, prey self-activation, nonspecific binding, and reduplication of interactions by matrix mating with stringent controls, that further reduces false positives. Fourteen LYST cDNA fragments covering the coding domain were cloned into activationand DNA binding-domain vectors. These baits preserved the proposed structural features of LYST. Human heart, keratinocyte, fetal brain, fetal liver, and fetal kidney cDNA libraries were screened for LIPs. Bait and prey constructs were transformed into complementary haploid yeast and mated on 96-well plates in a high-throughput manner. The interactions shown (Tables 2 and 3) passed all quality controls.

\section{Interactions Identified in Forward Screens}

Four known proteins were found to interact with LYST in forward screens (Table 2). The LYST Nterminus interacted with $14-3-3$ tau $(\tau$, also called 14-3-3 theta). Seven independent isolates of 14-3-3 $\tau$ were identified in screens with three libraries (heart, fetal brain, and fetal liver). The $5^{\prime}$ end of all of these isolates was within the N-terminal one-third of 14-3$3 \tau$. Because prey libraries had been constructed with oligo-dT primed cDNA, it was assumed that the 3' ends of prey inserts corresponded to the stop codon.
This region of 14-3-3 $\tau$ was also found to interact with the LYST N-terminus in reverse screens (see below).

Seventy-two colonies, representing nine independent isolates, of CK2 $\beta$ subunit were found to interact with LYST bp3190-4032 (Table 2). LYST-CK $2 \beta$ interactions were identified in all libraries screened. The $5^{\prime}$ end of the CK $2 \beta$ isolates was in the vicinity of the start codon.

Screening against a human heart library revealed two independent isolates of an interaction between LYST bp3190-4032 and troponin I.

Hepatocyte growth factor-regulated tyrosine kinase substrate (HRS) was found to interact with LYST fragment 6586-7449. This sequence was isolated once from a screen of a fetal brain cDNA library. The $5^{\prime}$ end of the HRS clone corresponded to amino acid 84 .

\section{Interactions Identified in the Reverse Screens}

Twenty-two LIPs were identified in reverse screens (Table 3). Thirteen were known proteins and nine were novel. All of these interactions were confirmed in vivo. The interaction of the LYST N-terminus with 14-3-3 $\tau$ that had been identified by the forward screen was recapitulated in the reverse screens in four colonies, representing two independent isolates. Another LYST fragment (bp 4009-4821) interacted with the same region of $14-3-3 \tau$. This interaction was found only once.

Table 2. Confirmed LYST interactions identified by forward yeast two-hybrid screens

\begin{tabular}{|c|c|c|c|c|c|}
\hline $\begin{array}{l}\text { LYST } \\
\text { Bait (bp*) }\end{array}$ & Prey (GenBank \#) & Prey Function & Prey Library & $\begin{array}{c}\text { First } \\
\text { Nucleotide of } \\
\text { Prey Clones }\end{array}$ & $\begin{array}{l}\text { \# Yeast } \\
\text { Colonies }\end{array}$ \\
\hline $190-1056$ & $14-3-3 \tau(\mathrm{X} 56468)$ & $\begin{array}{l}\text { Vesicular trafficking } \\
\text { and signal transduction }\end{array}$ & $\begin{array}{l}\text { Fetal liver } \\
\text { Adult heart } \\
\text { Fetal brain } \\
\text { Fetal liver } \\
\text { Fetal brain } \\
\text { Fetal liver } \\
\text { Fetal brain }\end{array}$ & $\begin{array}{l}185 \\
221 \\
290 \\
299 \\
308 \\
322 \\
342\end{array}$ & $\begin{array}{l}1 \\
1 \\
1 \\
2 \\
1 \\
1 \\
1\end{array}$ \\
\hline $3190-4032$ & $\begin{array}{l}\text { Casein kinase II } \beta \text {-subunit, } \\
\text { CK2 } \beta \text { (M30448) }\end{array}$ & $\begin{array}{l}\text { Phosphorylation: } \\
\text { vesicular trafficking and } \\
\text { signal transduction }\end{array}$ & $\begin{array}{l}\text { Fetal brain } \\
\text { Adult heart } \\
\text { Fetal liver } \\
\text { Keratinocyte } \\
\text { Fetal kidney } \\
\text { Keratinocyte } \\
\text { Fetal brain } \\
\text { Fetal brain } \\
\text { Fetal brain } \\
\text { Adult heart } \\
\text { Adult heart }\end{array}$ & $\begin{array}{r}1 \\
1 \\
1 \\
1 \\
2 \\
3 \\
5 \\
35 \\
86 \\
1 \\
75\end{array}$ & $\begin{array}{r}28 \\
14 \\
12 \\
11 \\
1 \\
1 \\
1 \\
1 \\
3 \\
6 \\
3\end{array}$ \\
\hline $6586-7449$ & $\begin{array}{l}\text { Hepatocyte growth } \\
\text { factor-regulated tyrosine } \\
\text { kinase substrate, } \\
\text { HRS (D84064) }\end{array}$ & $\begin{array}{l}\text { Vesicular trafficking } \\
\text { and signal transduction }\end{array}$ & Fetal brain & 309 & 1 \\
\hline
\end{tabular}

*From GenBank U67615. 
Table 3. Confirmed LYST interactions identified by reverse yeast two-hybrid screens with a fetal brain prey library

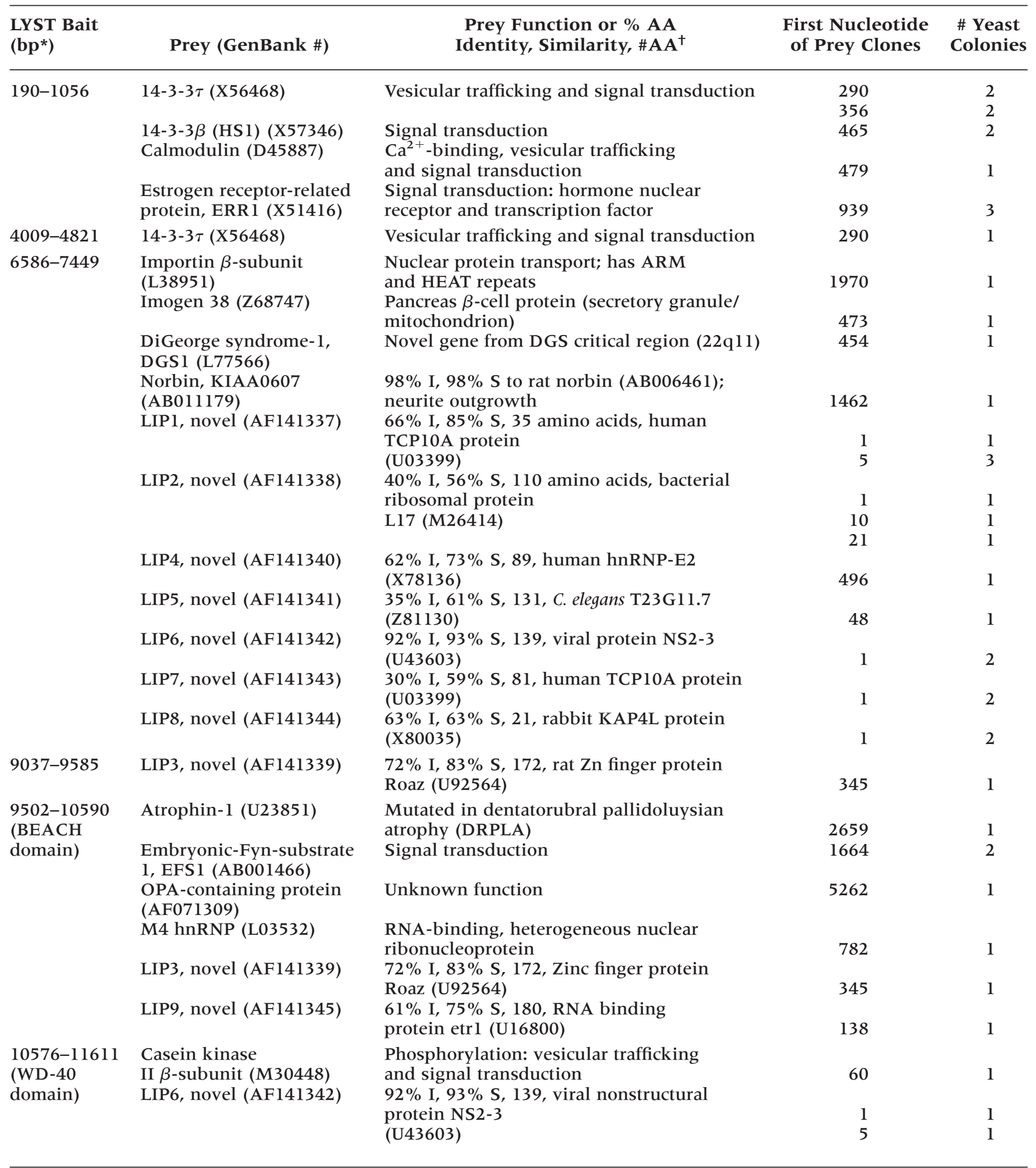

*From GenBank \# U67615.

${ }^{\dagger}$ \#AA designates the number of amino acids in the region of LYST-IP, for which the \% identity/similarity is shown.

Abbreviations: I, identity; S, similarity. 
In addition to $14-3-3 \tau$, the LYST $\mathrm{N}$-terminus interacted with 14-3-3 $\beta$ (also called HS 1 and 14-3-3 $\alpha$ ), which has $82 \%$ amino acid identity to $14-3-3 \tau$. The LYST-interaction region of $14-3-3 \beta$ was the same as the LYST-interaction region of $14-3-3 \tau$. The $14-3-3 \beta$ interaction was identified twice in screens of a fetal brain library.

LYST N-terminus also interacted with the Cterminus of calmodulin (CALM), an interaction identified once in a screen of a fetal brain library. The LYST $\mathrm{N}$-terminus also interacted with the C-terminal half of a steroid hormone receptor, estrogen receptor-related protein (ERR 1), an interaction detected three times in a screen of a fetal brain library.

LYST fragment 6586-7449 interacted with 11 proteins: the C-terminal halves of the importin $\beta$-subunit, imogen 38, and norbin; DGS-I, a gene from the DiGeorge syndrome critical region; and 8 novel genes (LIP1, LIP2, LIP4-LIP8). In addition to LYST 6578-7449, LIP6 interacted with the LYST domain containing WD40 repeats (bp 10576-11611). Two independent isolates of LIP6 were identified among interactions with the WD40 domain. CK2 $\beta$ also interacted with the LYST WD40 repeat domain.

The BEACH domain of LYST (bp 9502-10590) interacted with six proteins: the amino terminal third of atrophin-1 and embryonic Fyn substrate-1 (EFS1), the N-terminus of OPA-containing protein, heterogeneous nuclear riboprotein M4, LIP3, and LIP9. LIP3 also interacted with LYST 9037-9585.

\section{Biochemical Confirmation of LYST Interactions}

Four of five interactions of LYST were confirmed by an in vitro binding assay (Fig. 1). HRS, 14-3-3 $\tau$, and CK $2 \beta$ proteins were purified and incubated with respective LYST peptides. Specifically bound proteins were isolated, resolved electrophoretically, and identified on Western blots. Interactions of LYST with
HRS, 14-3-3 $\tau$, and CK $2 \beta$ were confirmed: HRS bound to LYST 6586-7449 but not to a negative control. 14-3$3 \tau$ bound to the LYST N-terminus and LYST 40094821 , but not to a negative control. CK2 $\beta$ bound to LYST 3190-4032, but not to a negative control. The interaction of CK2 $\beta$ with the LYST WD40 domain failed confirmation by this method.

\section{Discussion}

A modified $\mathrm{Y} 2 \mathrm{H}$ method was used to identify potential substrates of LYST action, using 14 LYST baits and 5 prey libraries. The baits were designed to preserve the proposed structural features of LYST. For example, the BEACH domain (10) was included in its entirety in the bait spanning bp 9502-10590, the bait extending over bp 10576-11611 contained the WD-40 domain, and the stathmin-like region was preserved in the bait encompassing bp 1051-1950. Six of the baits (derived from the first $\sim 4700$ bp of $C H S$ ) were common for the large and small isoforms (9-11) of the CHS protein, whereas eight baits were specific only for the large isoform. Prey libraries from tissues that are severely affected in CHS were used in the screens. For example, in CHS patients and animal models, numerous abnormalities have been described in the brain $(14,15)$, kidney $(16,17)$, keratinocytes $(18)$, and hepatocytes $(19,20)$. Authentic interactions were anticipated to involve cytoplasmic proteins because LYST is cytosolic $(3,12)$. Of 24 interacting proteins that passed in vivo confirmation tests, 12 were known proteins and 12 were novel. In addition, LYST interactions with HRS, 14-3-3 $\tau$, and CK2 $\beta$ were confirmed in vitro. Several of the interacting proteins regulate vesicular transport or signal transduction, and provide potential explanations of the mechanism whereby absence of LYST causes CHS.

Although detected once, the interaction with HRS passed in vivo and in vitro confirmation tests.

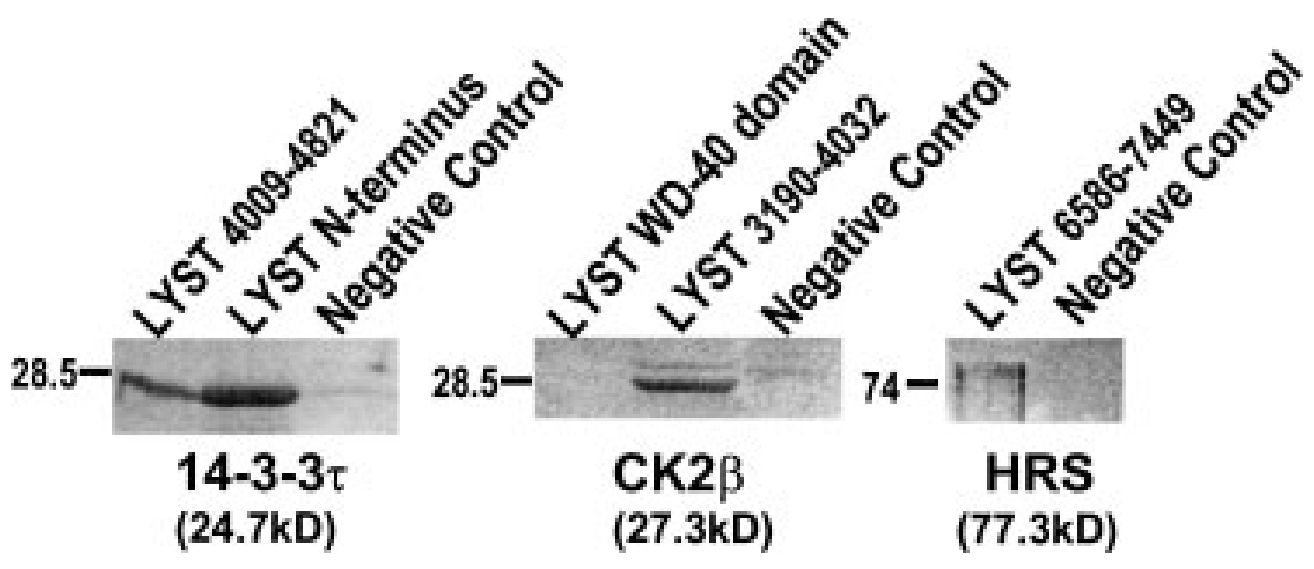

Fig. 1. Biochemical confirmation of interactions of LYST with 14-3-3 $\tau$, CK2 $\beta$, and HRS by an in vitro binding assay. Following binding, the eluted proteins were resolved by SDS-PAGE, Western blotted, and detected with specific antibodies. LYST N-terminal domain: nucleotides 190-1056. LYST WD-40 (C-terminal) domain: nucleotides 10576-11611. 14-3-3 $\tau$ negative control: LYST C-terminus. CK2- $\beta$ negative control LYST 6586-7449. HRS negative control: LYST N-terminus. All interactions were confirmed except that between CK2 $\beta$ and the LYST WD-40 domain. Molecular size standards (in kD) are shown. LYST nucleotide positions are derived from GenBank U67615. 
Like LYST, HRS is a cytoplasmic protein that attaches reversibly to the cytoplasmic surface of endosomes (21-23). The region of HRS that interacts with LYST contains a zinc finger domain and an ATPase catalytic site. The HRS-LYST interaction is compelling because HRS inhibits exocytosis by binding to SNAP25, a component of the SNARE protein complex that is important in vesicle docking and fusion (23-25). $\mathrm{Ca}^{2+}$ and $\mathrm{Zn}^{2+}$ inhibit binding of HRS to SNAP25 and promote exocytosis. HRS is similar in sequence to $S$. cerevisiae Vps27p, which is essential for protein transport to the vacuole (26). In binding to LYST, HRS may become unavailable for interaction with SNAP25 (Fig. 2). Thus, LYST may promote membrane docking by preventing the inhibitory effects of HRS on SNARE assembly. Alternatively, LYST-complexed HRS may have an increased affinity for SNAP25, augmenting the inhibitory effect of HRS on SNARE assembly. In this case, LYST would inhibit membrane docking and fusion.

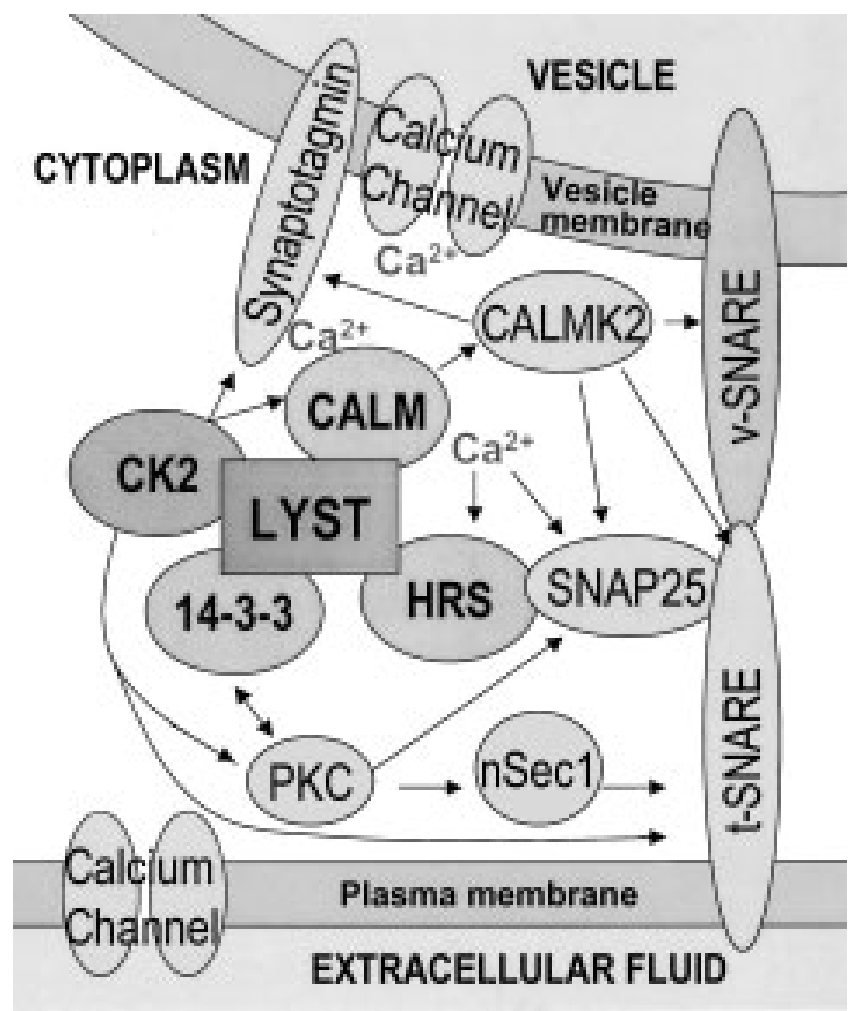

Fig. 2. Interactions of LYST with proteins that regulate vesicle docking and fusion in exocytosis. Not all salient interactions are shown (e.g., synaptotagmin also interacts with syntaxin; syntaxin is phosphorylated by CALMK2). According to this hypothesis, LYST binds to HRS, modifying HRSmediated modulation of SNAP25, a component of the tSNAREvSNARE docking complex. LYST also binds to CALM, bringing $\mathrm{Ca}^{2+}$ into the proximity of HRS, inhibiting HRS binding to SNAP25. Docking leads to transient opening of $\mathrm{Ca}^{2+}$ channels, and $\mathrm{Ca}^{2+}$-CALM complexes activate membrane fusion. LYST interacts with 14-3-3 and CK2, which modify activity of several proteins of the tethering, docking, and fusion machinery.
HRS also interacts with STAM, a relay in intracellular signal transduction (21). Binding of HRS to STAM suppresses signaling, an interesting result; intracellular signal transduction is abnormal in CHS. CHS granulocytes have abnormal concavalinA-induced capping associated with decreased PKC (27). Normalization of PKC activity rectifies the CHS capping defect and ameliorates the lysosomal abnormalities (28-29). Thus, interaction of LYST with HRS may potentially explain the lysosomal exocytosis and capping abnormalities of CHS.

Another provocative interaction of LYST is with CALM, a cytoplasmic $\mathrm{Ca}^{2+}$-binding protein. LYST interacted with the C-terminus of CALM, which forms the end of a $\mathrm{Ca}^{2+}$-binding site and an $\alpha$-helix. CALM has previously been shown to bind many proteins in $\mathrm{a} \mathrm{Ca}^{2+}$-dependent manner. The LYST-CALM interaction did pass in vivo confirmation tests but was not evaluated in vitro. CALM has a significant role in membrane fusion: it binds to intracellular organelles, such as secretory granules, and is required for membrane fusion and exocytosis in cell types important in CHS such as platelets and leukocytes (30-32). In particular, SNARE-mediated docking of acidic organelles has been shown to prompt local $\mathrm{Ca}^{2+}$ release, causing CALM to bind tightly to the docked vesicle and promote membrane fusion. Furthermore, $\mathrm{Ca}^{2+}$ inhibits interaction of HRS and SNAP25. A ternary complex of LYST, HRS, and CALM would be anticipated to juxtapose HRS and $\mathrm{Ca}^{2+}$, inhibiting HRS-SNAP25 binding (Fig. 2). Such LYST/CALM-mediated inhibition of HRS action would be anticipated to enhance SNAP25-regulated membrane docking and fusion (23-25). In CHS, the absence of LYST might prevent juxtaposition of HRS and CALM, potentiating HRS inhibition of SNAP25, and inhibiting membrane docking and fusion.

Other confirmed interactions of LYST were with 14-3-3 proteins $14-3-3 \tau$ and 14-3-3 $\beta$, members of a highly conserved gene family involved in both exocytosis and signal transduction (33). The LYST-interacting domain of 14-3-3 $\tau$ included an annexin-like region important in promoting $\mathrm{Ca}^{2+}$-regulated exocytosis $(34,35)$. The LYST-interacting domain of $14-3-3 \beta$ was the same, but also included a PKC-inhibition domain. Neither of the 14-3-3-interacting domains of LYST contained the consensus binding motif (36). An interaction with 14-3-3 $\tau$ was also observed with LYST2, a novel LYST-related gene that is expressed only in brain (Tchernev et al., unpublished results).

14-3-3 proteins may be either membraneassociated or cytosolic $(37,38)$. They prime $\mathrm{Ca}^{2+}$ dependent exocytosis in a PKC-dependent manner $(30,39,40)$. 14-3-3 proteins are also important in signal transduction: $14-3-3 \tau$ binds PKC, is phosphorylated by PKC, and inhibits PKC activity (41). The PKC abnormalities described in CHS are similar to the effects of 14-3-3 on PKC $(28,29)$. 14-3-3 also binds to several kinases, such as Raf-1 and Bcr. 14-3-3 has also been proposed to function as a scaffold protein 
that facilitates interactions among components of signaling and exocytic pathways (33).

CK2, a ubiquitous serine/threonine protein kinase, is another LYST interactant associated with signal transduction and vesicular trafficking. $\mathrm{Nu}-$ merous colonies representing interactions between CK $2 \beta$ and LYST fragment 3190-4032 were observed with all prey libraries tested, whereas the interaction of CK2 $\beta$ with the WD-40 domain-containing LYST 10576-11611 was detected only once. The LYST 3190-4032-CK2 $\beta$ interaction was also confirmed in vivo and in vitro. $\mathrm{CK} 2 \beta$ is a regulatory subunit that modulates interactions with CK substrates (42). Several of these substrates are important in vesicular transport, including synaptotagmin, syntaxin, synaptobrevin, CALM, PKC, UNC18, and clathrin. A potential function of LYST suggested by interactions with both CK2 $\beta$ and the CK2 substrates CALM, PKC, and HRS, is to provide a scaffold that facilitates juxtaposition of proteins important in vesicular transport and signal transduction.

Other interactants included several proteins involved in signal transduction (BMKl $\alpha$ kinase, embryonic Fyn substrate (Efs 1), Fos-transformation effector-1, and KB07, a novel gene similar in sequence to tyrosine kinases) and 12 proteins of completely unknown function. These interactions passed the in vivo confirmation tests and may also be significant for LYST function.

The BEACH domain (10) of LYST (bp 9502-10590) interacted with three known proteins (Table 3), some of which participate in signal transduction, as well as with three proteins with unknown function, two of which were novel (LIP3 and LIP9). Although the role of the BEACH domain remains unclear, it is possible that through its multiple interactions, this domain facilitates the association of other proteins involved in vesicular transport.

Interestingly, all known CHS mutations are predicted to result in the production of either truncated or absent proteins (9-11). Compared to the positions of the baits used in this study, in two CHS patients the premature termination occurs in the region of bait190-1056, which we detected to interact with 14-3-3 $\tau$ in the forward screen, and with 14$3-3 \tau, 14-3-3 \beta$, calmodulin, and ERR 1 in the reverse screen. In another patient, the premature stop codon was found at a location corresponding to bait 10511950 (containing the stathmin-like domain), and in three other CHS patients the premature termination occurs in the region of bait 3190-4032, which interacts with CK $2 \beta$ in the forward screen (Table 2). Premature stop codons have also been reported at positions corresponding to bait 2347-3213 (43), as well as to bait 1948-2370 and bait 9502-10590 (44), which contains the BEACH domain and interacts with six proteins in the reverse yeast-two hybrid screen (Table 3). Mutations in seven additional patients have recently been described (45), occurring in regions of LYST corresponding to baits 3190-4032,
4819-5700, 6586-7449, 7426-8238, 9037-9585, and 9502-10590, which we found to interact with multiple proteins, including HRS and CK2 $\beta$. All $16 \mathrm{mu}-$ tations reported in the literature result in premature termination, indicating that substitutions may lead to a milder phenotype, which may not be recognized as CHS. Mutations producing truncated CHS proteins do not allow evaluation of the effect of individual amino acid changes on the observed protein interactions, because they prevent binding of multiple CHS regions (baits) to their corresponding interacting proteins. However, the interactions that we found using baits from the C-terminal portions of LYST (e.g., BEACH domain and WD-40 motifs) confirm the suggestion (44) that the complete CHS protein is required for its proper function, and show that in all of the described patients the truncated CHS protein will not interact with a number of the detected interacting proteins, leading to defective vesicular transport and clinical manifestations of CHS.

In addition to contributing to an understanding of the role of LYST lysosome biology, identification of LIPs is significant for the treatment of CHS and diseases associated with excessive exocytosis of lysosomal contents. Diseases such as asthma and urticaria largely are the result of inappropriate local degranulation by leukocytes and mast cells. An attractive therapeutic strategy for these disorders would be to recapitulate the lazy lysosome phenotype of CHS in a controlled manner with a small molecule antagonist. The observation that CHS mice are protected from the inflammatory disease lupus nephritis (46) suggests that this approach may also be an effective treatment for autoimmune diseases. Although LYST is not a suitable target for conventional drug development, several LIPs, such as HRS (an ATPase), are potential drug targets. Further validation of the significance of these LIPs in vesicle exocytosis is indicated, for example by colocalization studies in the organelles of interest.

\section{Acknowledgments}

We thank Naomi Kitamura for provision of the antiHrs antibody and Pietro de Camilli for reviewing the manuscript. S.F.K. was supported by the American Cancer Society, the Arthritis Foundation, the Howard Hughes Medical Institute, and the National Institutes of Health.

\section{References}

1. Targan SR, Oseas R. (1983) The "lazy" NK cells of ChediakHigashi syndrome. J. Immunol. 130: 2671-2674.

2. Burkhardt JK, Wiebel FA, Hester S, Argon Y. (1993) The giant organelles in beige and Chediak-Higashi fibroblasts are derived from late endosomes and mature lysosomes. J. Exp. Med. 178: 1845-1856.

3. Faigle W, Raposo G, Tenza D, et al. (1998) Deficient peptide loading and MHC class II endosomal sorting in a human genetic immunodeficiency disease: the Chediak-Higashi Syndrome. J. Cell. Biol. 141: 1121-1134. 
4. Blume RS, Bennett JM, Yankee RA, Wolff SM. (1968) Defective granulocyte regulation in the Chediak-Higashi syndrome. N. Engl. J. Med. 279: 1009-1015.

5. Roder JC, Haliotis T, Klein M, et al. (1980) A new immunodeficiency disorder in humans involving NK cells. Nature 284: 553-555.

6. Baetz K, Isaaz S, Griffiths GM. (1995) Loss of cytotoxic T lymphocyte function in Chediak-Higashi syndrome arises from a secretory defect that prevents lytic granule exocytosis. $J$. Immunol. 154: 6122-6131.

7. Windhorst DB, Zelickson AS, Good RA. (1966) ChediakHigashi syndrome: hereditary gigantism of cytoplasmic organelles. Science 151: 81-83.

8. Rendu F, Breton-Gorius J, Lebret M, et al. (1983) Evidence that abnormal platelet functions in human Chediak-Higashi syndrome are the result of a lack of dense bodies. Am. J. Pathol. 111: 307-314.

9. Barbosa MDFS, Nguyen QA, Tchernev VT, et al. (1996) Identification of the homologous beige and Chediak-Higashi syndrome genes. Nature 382: 262-265.

10. Nagle DL, Karim MA, Woolf EA, et al. (1996) Identification and mutation analysis of the complete gene for ChediakHigashi syndrome. Nat. Genet. 14: 307-311.

11. Barbosa MDFS, Barrat FJ, Tchernev VT, et al. (1997) Identification of mutations in two major mRNA isoforms of the Chediak-Higashi syndrome gene in human and mouse. Hum. Mol. Genet. 6: 1091-1098.

12. Perou CM, Leslie JD, Green W, Li L, Ward DM, Kaplan J. (1997) The Beige/Chediak-Higashi syndrome gene encodes a widely expressed cytosolic protein. J. Biol. Chem. 272: 29790-29794.

13. Uetz P, Giot L, Cagney G, et al. (2000) A comprehensive analysis of protein-protein interactions in Saccharomyces cerevisiae. Nature 403: 623-627.

14. Uyama E, Hirano T, Ito K, et al. (1994)Adult Chediak-Higashi syndrome presenting as parkinsonism and dementia. Acta Neurol. Scand. 89: 175-183.

15. Kondo N, Shimozawa N, Asano J, Imamura A, Orii T. (1994) Chediak-Higashi syndrome with cerebellar cortical atrophy detected by MRI. Clin. Genet. 46: 439-440.

16. Hargis AM, Prieur DJ. (1987) Animal model: renal lesions in cats with Chediak-Higashi-Steinbrinck syndrome. Am. J. Med. Genet. 26: 169-179.

17. Eguchi M, Poon KC, Spicer SS. (1982) Alterations in the proximal nephron of beige mice with the Chediak-Higashi syndrome. Am. J. Pathol. 106: 95-109.

18. Deprez P, Laurent R, Griscelli C, Buriot D, Agache P. (1978) Chediak-Higashi disease (report on a new case). Ann. Dermatol. Venereol. 105: 841-849.

19. Hargis AM, Prieur DJ. (1985) Animal model. Light and electron microscopy of hepatocytes of cats with ChediakHigashi syndrome. Am. J. Med. Genet. 22: 659-668.

20. Ozaki K, Maeda H, Nishikawa T, Nishimura M, Narama I. (1994) Chediak-Higashi syndrome in rats: light and electron microscopical characterization of abnormal granules in beige rats. J. Comp. Pathol. 110: 369-379.

21. Asao H, Sasaki Y, Arita T, et al. (1997) HRS is associated with STAM, a signal transducing adaptor molecule. J. Biol. Chem. 272: 32785-32791.

22. Komada M, Masaki R, Yamamoto A, Kitamura N. (1997) HRS, a tyrosine kinase substrate with conserved double zinc finger domain, is localized to the cyto-plasmic surface of early endosomes. J. Biol. Chem. 272: 20538-20544.

23. Bean AJ, Seifert R, Chen YA, Sacks R, Scheller RH. (1997) HRS-2 is an ATPase implicated in calcium-regulated secretion. Nature 385: 826-829.

24. Ungermann C, Sato K, Wickner W. (1998) Defining the functions of trans-SNARE pairs. Nature 396: 543-548.

25. Banerjee A, Kowalchyk JA, Das Gupta BR, Martin TFJ. (1996) SNAP-25 is required for a late postdocking step in $\mathrm{Ca}^{2+}$-dependent exocytosis. J. Biol. Chem. 271: 20227-20230.

26. Piper RC, Cooper AA, Yang H, Stevens TH. (1995) VPS27 controls vacuolar and endocytic traffic through a prevacuolar compartment in Saccharomyces cerevisiae. J. Cell Biol. 131: 603-617.
27. Oliver JM, Zurier RB, Berlin RD. (1975) Concavalin A cap formation on polymorphonuclear leukocytes of normal and beige (Chediak-Higashi) mice. Nature 253: 471-473.

28. Ito $M$, Sato A, Tanabe F, Ishida E, Takami $Y$, Shigeta S. (1989) The thiol proteinase inhibitors improve the abnormal rapid down-regulation of protein kinase $\mathrm{C}$ and the impaired natural killer cell activity in (Chediak-Higashi syndrome) beige mouse. Biochem. Biophys. Res. Commun. 160: 433-440.

29. Sato A, Tanabe F, Ito M, Ishida E, Shigeta S. (1990) Thiol proteinase inhibitors reverse the increased protein kinase $\mathrm{C}$ down-regulation and concavalin A cap formation in polymorphonuclear leukocytes from Chediak-Higashi syndrome (beige) mouse. J. Leukoc. Biol. 48: 377-381.

30. Chamberlain LH, Roth D, Morgan A, Burgoyne RD. (1995) Distinct effects of $\alpha$-SNAP, 14-3-3 proteins and calmodulin on priming and triggering of regulated exocytosis. J. Cell Biol. 130: $1063-1070$.

31. Peters C, Mayer A. (1998) $\mathrm{Ca}^{2+} /$ calmodulin signals the completion of docking and triggers a late step in vacuole fusion. Nature 396: 575-580.

32. Schekman R. (1998) Ready ... aim ... fire! Nature 396: 514-515.

33. Aitken A, Jones D, Soneji Y, Howell S. (1995) 14-3-3 proteins: biological function and domain structure. Biochem. Soc. Trans. 23: 605-611.

34. Roth D, Morgan A, Burgoyne RD. (1993) Identification of a key domain in annexin and 14-3-3 proteins that stimulate calcium-dependent exocytosis in permeabilized adrenal chromaffin cells. FEBS Lett. 320: 207-210.

35. Jones DH, Martin H, Madrazo J, et al. (1995) Expression and structural analysis of 14-3-3 proteins. J. Mol. Biol. 245: 375-384.

36. Yaffe MB, Rittinger K, Volinia S, et al. (1997) The structural basis for 14-3-3:phosphopeptide binding specificity. Cell 91: 961-971.

37. Martin H, Rostas J, Patel Y, Aitken A. (1994) Analysis of subcellular distribution of 14-3-3 isoforms in rat brain using specific antibodies. J. Neurochem. 63: 2259-2265.

38. Roth D, Morgan A, Martin H, Jones D, martens GJ, Aitken A, Burgoyne RD. (1994) Characterization of 14-3-3 proteins in adrenal chromaffin cells and demonstration of isoformspecific phospholipid binding. Biochem. J. 301: 305-310.

39. Burgoyne RD, Morgan A, Robinson I, Pender N, Cheek T. (1993) Exocytosis in adrenal chromaffin cells. J. Anat. 183: 309-314.

40. Roth D, Burgoyne RD. (1995) Stimulation of catecholamine secretion from adrenal chromaffin cells by 14-3-3 proteins is due to reorganisation of the cortical actin network. FEBS Lett. $374: 77-81$.

41. Meller N, Liu YC, Collins TL, Bonnefoy-Berard N, Baier G, Isakov N, Altman A. (1996) Direct interaction between protein kinase $\mathrm{C}$ theta (PKC theta) and 14-3-3 tau in T cells: 14-3-3 overexpression results in inhibition of PKC theta translocation and function. Mol. Cell. Biol. 16: 5782-5791.

42. Allende JE, Allende CC. (1995) Protein kinase CK2: an enzyme with multiple substrates and a puzzling regulation. FASEB J. 9: 313-323.

43. Dufourcq-Lagelouse R, Lambert N, Duval M, et al. (1999) Chediak-Higashi syndrome associated with maternal uniparental isodisomy of chromosome 1. Europ. J. Hum. Genet. 7: 633637.

44. Karim MA, Nagle DL, Kandil HH, Burger J, Moore KJ, Spritz RA. (1997) Mutations in the Chediak-Higashi syndrome gene (CHS1) indicate requirement for the complete 3801 amino acid CHS protein. Hum. Molec. Genet. 6: 1087-1089.

45. Certain S, Barrat F, Pastural E, et al. (2000) Protein truncation test of LYST reveals heterogenous mutations in patients with Chediak-Higashi syndrome. Blood 95: 979-983.

46. Clark EA, Roths JB, Murphy ED, Ledbetter JA, Clagett JA. (1982) The beige (bg) gene influences the development of autoimmune disease in SB/Le male mice. In Heberman RB (ed). NK Cells and Other Natural Effector Cells. New York: Academic Press; pp. 301-306. 